\title{
Handing Down and Writing Down : Metadiscourses of Tradition among the Bandanese of Eastern Indonesia
}

\section{Kaartinen, Timo}

\section{3}

Kaartinen , T 2013 , ' Handing Down and Writing Down : Metadiscourses of Tradition among the Bandanese of Eastern Indonesia ' , Journal of American Folklore , vol. 126 , no. 502 , pp. 385-406 . < http://www.jstor.org/stable/10.5406/jamerfolk.126.502.0385 >

http://hdl.handle.net/10138/42148

acceptedVersion

Downloaded from Helda, University of Helsinki institutional repository.

This is an electronic reprint of the original article.

This reprint may differ from the original in pagination and typographic detail.

Please cite the original version. 


\section{Handing Down and Writing Down: Metadiscourses of Tradition among the Bandanese of Eastern Indonesia}

The topic of this article is the reproduction of tradition among the Bandanese, an Eastern Indonesian people. I analyze the style and rhetoric of songs that tell about ancestral sea voyages. The question I address is what happens to the value of the songs as tradition when they turn from oral performances into circulating texts. I explore several contexts of performance and transmission and argue that the songs can be embedded in lived realities in different ways. By writing the songs down, the Bandanese reorganize their tradition into new genres of text and performance. Their metadiscourse of tradition affirms that these genres represent the exemplary, complete language of the ancestors. Although singers and writers affirm the artistic, textual, and cultural completeness of their arts, they are reluctant to pass on their knowledge in an already integrated form.

Keywords

AFS ETHNOGRAPHIC THESAURUS: Indigenous peoples, musical genres, written tradition, ethnopoetics, human migration

MODERN FOLKLORISTICS AND LINGUISTIC anthropology have given up the view in which tradition consists of fixed linguistic forms and texts that one generation hands down to the next. People living in new times and places receive tradition as sediments and fragments of past discourse. In order to maintain their status as emblematic cultural items, these fragments must either be re-performed and re-embedded in actual discourse contexts or turned into new, distinctive texts that somehow resemble speech and knowledge of the past (Silverstein and Urban 1996:13). In this article I ask how this happens during rapid social change. How can people recover the powerful meaning of traditional genres if they no longer hear them being performed? What models of tradition do they follow when they turn ancestral songs and stories into written records?

There are at least two ways in which traditional language can be reproduced as a significant part of social practices. Recent linguistic anthropology has explored situations 
in which "exemplary uses of language" (Errington 1998:40) survive even though the sociolinguistic context in which they used to mark and mediate the difference of status has vanished. Joel Kuipers (1998:65) argues that traditional forms of language survive because they continue to offer meaningful models for self-expression in new historical situations. But there are also situations in which people historicize new situations in traditional terms. When people refer to ancestral songs, sacred myths, public oratory, and other types of exemplary language as the grounds of their place in the socio-cultural world, they are sometimes less concerned with their authenticity than their persuasive effects. Attention shifts from the performance of traditional discourse to contestations of its meaning. In this case, tradition is present as a metadiscourse: talk and behavior that stand for memory about the past.

I aim to apply a communicative approach to both kinds of situations and to look at them as different phases in the same historical process. Tradition is clearly not handed down as stable genres that are either recovered or lost. But instead of giving up a focus on genre and performance, I find it useful to expand the use of these concepts beyond clear-cut domains of traditional performance. Ethnopoetics has stressed the connection between linguistic forms and rhetorical purposes, which, in skillful traditional performances, amounts to a narrative organization of cultural experience (Blommaert 2006:260). Such performances "hand down" tradition by putting the audience in the presence of moral instructions and powerful existential insights.

Recent linguistic anthropology has stressed that performances can also have the opposite, entextualizing effect (Bauman and Briggs 1990:73). The increasing poetic and rhetorical patterning of discourse creates the impression that it exists outside the current dialogic setting, as a text-like entity inherited from the distant past (Kuipers 1990:4; Keane 1997:40). Such effects rely on an ideological notion in which language itself is a totality. Such notions are common in the societies of Eastern Indonesia, the ethnographic context discussed in this article (Traube 1986; Fox 1988).

The Platonic notion of handing down tradition points to such totalizing ideas about language that often stand for cultural wholeness and integrity (Kuipers 1998:7). For Platonism, "writing things down" was merely an imperfect way of keeping the memory of what one had received. For us, of course, it is the other way around. In order to understand ideological forms, we study the practices of discourse production. But is this possible without some account of the models and categories that orient discourse? Whenever people finalize discourse, or "make a point," they necessarily address people who occupy a different position in the social world. Minimally they take into account the categories of time and place that differentiate that world. This was the basic insight in Mikhail Bakhtin's (1981:84) definition of genre. Meaningful speech is possible because our genre categories allow us to imagine how people who live in other places and times would understand it (Bakhtin 1986:126).

From this basis it is possible to argue that traditional language expressions are culturally structured. Metadiscourses of tradition construct other places and times (and the genres they define) as important for us, either because they are closely connected to our life or because they stand for its opposite (Briggs 1996:449). But from the opposite perspective, argued by Johannes Fabian, the audience to which tradition 
and any commemorative discourse addresses itself is not imagined but real. The world is not really differentiated into times and places before people challenge each other to either remember or forget some things about it (Fabian 2007:79). What must come first is "memory work," the concrete effort of making the time that interacting subjects share together (Fabian 2007:38).

In this article I will discuss several practices that correspond to this notion of memory work. I am concerned with people who show little interest in passing on their tradition in the same form, and yet affirm its continuity as ancestral messages. The question is what kind of completeness they expect to achieve through this production of discourse: exemplary language or recognition from social others?

\section{The Time and Place of Memory}

The ethnographic material of this article is drawn from my fieldwork among the Bandanese, a small ethnolinguistic group in the Eastern Indonesian islands of Maluku. ${ }^{1}$ Their ancestors were refugees from the spice-producing islands of Banda. The Dutch East India Company conquered Banda in 1621 and massacred or enslaved most of its original population. A few hundred Bandanese survived the massacre and founded two villages, Banda Eli and Banda Elat, in the Kei Islands, some 500 kilometers southeast of their former home. Their descendants kept their Muslim faith and continued to speak their own language, called turwandan or Bandanese (Collins and Kaartinen 1998), which is quite different from evav, the language of the Kei Islands majority.

I did my doctoral fieldwork in the Banda Eli village over 15 months in 1994-96. During this period the community was experiencing rapid urbanization and language shift. Many old people were still able to perform traditional Bandanese language songs about the migrations and sea voyages of their ancestors. In their youth, the songs were performed during funerals, weddings, travel rituals, chiefly appointments, and inter-village festivals. The children and grandchildren of the singers were still using Bandanese in everyday conversation among themselves, but in the village school and with outsiders, they spoke Indonesian, the national language. In most domains of language use, Indonesian had already eclipsed Bandanese as the vehicle of public speech.

In 2009 I returned to Maluku to study the Bandanese who lived in Ambon, the provincial capital, and in smaller urban centers across the islands of Maluku. Many of the people whom I had known as children in the village were now young adults who worked in harbors, fishing boats, and offices, or studied to become teachers, engineers, or civil servants. My return to the field opened up several new contexts in which the Bandanese sought to recover their ancestral culture.

One of these contexts was already forming in the early 1970s when Banda Eli people started to move to Ambon in large numbers. Housing land in the city was scarce, and in order to get access to it, they appealed to their ancestral kinship with certain landowning groups in Ambon. These groups trace their ancestry back to the historical trading aristocracy, which used to include the Bandanese refugees. The 
new settlers from Banda Eli affirmed their ties to Central Maluku by recovering and performing ancestral songs that demonstrated their Bandanese origin and helped them secure land rights in the Christian parts of the city.

Another context of reproducing tradition was the national public space. In the 1980s, young, educated Bandanese founded a cultural association in response to the Indonesian policy of cultural diversity. They were responding to the Indonesian national discourse in which ethnic heritage has become an element of national identity (Pemberton 1994:9). National ideas of ethnic harmony came into crisis soon after the national government collapsed in 1998, but during my return fieldwork-a new period of relative stability-it was gaining new ground.

Since the cultural association represented Bandanese heritage to the general public, it is tempting to dismiss their cultural claims as inauthentic. Were the Bandanese simply inventing a new tradition in order to fit into the national model of cultural diversity? Charles Briggs (1996:436) has argued that we should not jump to such conclusions before taking a closer look at the people who identify with them. Even if some people claim cultural authority in the name of the whole group, it is not self-evident that they are creating a homogeneous image of its tradition. We should ask instead what kind of links they construct between the present and the past.

The first thing to note about the urbanized Bandanese is that they had little interest in recreating a complete, authoritative account of their culture. Instead, they sought to recover, write down, and memorize ancestral songs, known to have impressed large audiences in the village festivals in which their grandparents had performed them many years ago. These highly specific histories of performance pointed to tradition as the embodied, personal knowledge of performers who, sometimes reluctantly, taught their songs to selected grandchildren. Instead of reproducing their tradition as a timeless whole, the Bandanese turned it into a part of the personal memory and life history of each participant.

Learning and performing traditional songs is part of producing social relationships. It produces shared experiences that unfold through time. There is a sense in which talking about the songs, with the associated work of listening and learning, makes the time in which real communication can happen (Fabian 2007:38). This is particularly obvious when we consider the songs as in-group communication. The Bandanese community is dispersed over a large area, and its members live in very different life situations. There is a lot of actual communication between them through visits, letters, and telephone calls. Yet, their traditional rhetoric carries an anxious concern about the gap between the lived world of those who are "traveling" and those who are at "home." Villagers will often remind their urban or traveling relatives to "remember" them, or not to "forget."

The subject of forgetting is, of course, not an abstracted, decontextualized memory. It is a matter of recognizing relationships. As Fabian suggests, "not forgetting" is a positive act. But there is still an unmistakable sense that people who live in the village, or have grown up there, have far more agency in remembering. Unlike the urban relatives, they know their ancestral language, and they have firsthand experience of the numerous cultural practices that are associated with remembering. 
There is no level playing field of memory, and for this reason, there are different genres of remembering.

One interesting genre is local language songs with a generic pop music background. Such songs are distributed on video disks throughout Indonesia. The video background of the songs alternates between the images of village grandmothers and the young urban relatives who miss them. It is significant that the grandmothers are silent. Instead of representing them as active participants, the videos convey the voice of young urban people, which underlines the nostalgic gap between urban and rural social worlds.

The relationship between singers and audiences was the perfect reverse in the village-based performances that I studied in the 1990s. Here, the singers were old ladies and occasionally men. Another contrast was between the narrative chronotopes. Whereas the videos focused on a wish to revisit idyllic village life, the village performances placed their narrative events in the chaotic, changing reality of the outside world.

The video songs made little effort to connect the two realities of town and village. Village performers, on the other hand, constructed different dimensions of their socio-cultural world into a spatial and temporal unity. Although their songs revolved around the sea travels of the ancestors, the emotional focus of their performance was often on contemporary relatives. Singers interrupted their performance to name a sick child, a fisherman missing at sea, or a daughter who was out of communication because of an argument in the family. By expressing their anxiety over such relatives, the performers recognized them as part of their lived time, which spanned between the ancestral past and the eagerly anticipated future communion with the missing, absent relatives.

Nostalgia in one type of songs, and anxiety in the second, is integral to the genre in both cases I have discussed. As Charles Briggs and Richard Bauman (1992:149) point out, however, all genres "leak" and take on new contextualizing elements from ongoing discourse. They argue that strategies of cultural reproduction are essentially strategies of managing the intertextual gaps that open between past and contemporary settings of discourse (Bauman 2004:7; Briggs 1996:449; Briggs and Bauman 1992:151). The above examples may stand for two different genres in the analytic sense, but in the eyes of their performers, they may still count as the same song. This is no longer a problem if we think about such variants as part of a metagenre, a complex of language use that people identify with their tradition.

William Hanks (1987:688) has proposed a helpful definition of genre as a schematic device that creates "double interpretable" text-works, ones that anticipate the response of multiple audiences and future generations. In this view, genre is not just a model for producing artistically complete cultural texts. More importantly, it offers a framework for connecting particular kinds of speech to particular kinds of experience. For instance, the Bandanese songs discussed in this article shift artfully from the distant, imagined world of the ancestors to the scene of mundane, domestic social engagements. This goes to show that traditional discourse, just like any discourse, can draw meaning from routinized perspectives on reality without losing its textual qualities (Hanks 1996:239). Following a similar perspective, Anna-Leena and Jukka Siikala (2005:90) argue that korero, a traditional genre of the Cook Islands, should be 
seen as an orienting framework that allows oral narratives to be represented and performed in different forms.

In the Banda Eli case, we may ask what kinds of people assume this kind of agency. I begin by describing the personalities and genres I encountered in my ethnography of Banda Eli singers (Kaartinen 2010). In the following section I compare two performances of a particular onotani song in order to show what linguistic and poetic forms constitute the model of this genre.

\section{Ancestral Songs and the Singers}

Bandanese folk poetry has evolved in the context of long-distance migrations. Its core genre is called onotani, which translates as "weeping." Most onotani are performed by a lone singer and without accompaniment. Their melody usually moves between three or four notes, and each line typically starts from a higher pitch than where it ends. Older singers generally sing in a low voice, showing less concern than younger singers toward maintaining a stable timbre of voice. Onotani are sung in a slow, even rhythm with frequent slides between two or more notes. ${ }^{2}$

Songs classified as onotani include several types of songs. Most of the onotani I have recorded consist of ritual incantations, short narratives, and lullabies. These songs are well known because women frequently sing them while putting children to sleep. Songs known as onotani tambola are accompanied by an orchestra of flutes and drums. These songs celebrate ancestral figures and places in a simple verse structure that allows group performance, and they are often performed to accompany dancing.

The association of onotani with sacred cultural knowledge is borne out by onotani halia, (pure onotani). These are larger compositions, performed in an obscure, archaic-sounding Bandanese, and may take up to half an hour to perform. Many of them are narratives about the sea voyages of a particular ancestor whose arrival in a new location marks the existence of one of the currently recognized Bandanese groups in that place.

Sung narratives about ancestral sea voyages typically end in a scene in which the travelers arrive at their destination and learn something crucial about their own identity. The poetic and rhetorical forms of onotani amount to a narrative organization of a specific cultural experience, one that revolves around displacement, seaborne trade, and travel.

At the time of their exile, the Bandanese belonged to a cosmopolitan trading community. They continued to maintain extensive trade networks between Maluku, Sulawesi, and the New Guinea coast for at least two centuries after the Dutch colonized Banda in 1621. Banda Eli was part of these networks, and its ancestral songs recount the routes and destinations of its maritime traders. Until recently, long-distance travel was a distinct phase in a recently married man's path to full adulthood, and Banda Eli men continue to emphasize migrant work in their life historical stories. Songs portray the arrival at foreign places as a moment of self-discovery, creating expectations about personal distinction. This orientation to long-distance travel plays an important role in mobilizing Banda Eli society. 
In principle, onotani songs are family secrets owned by patrilineal groups. However, they are not performed by men who claim to descend from the ancestors named in them: the performers are women who typically change their affiliation to the husband's lineage at marriage. A skilled performer of onotani will know the ancestral songs of her father's and mother's lineages as well as those associated with her husband's lineage, and possibly songs about people who are allied or subordinated to these lineages as well. Marriage alliances between powerful lineages can have transforming effects on residential groups known as the house (rumo), which consist of several hierarchically related lineages. In the eyes of outsiders, the house is constituted by its claims to important ritual and chiefly titles such as the imam (leader of prayer), orangkaya (rich man), or ratu (ruler). From the inside point of view, the house is constituted by the relations of descent between its members and the ancestors who held these titles at the time of their exile from Banda. A particular woman's repertoire of onotani songs commemorates the ancestral relationships that constitute the unity of the house. At the same time, it relativizes the view of the house as an element of a lasting political and social structure.

Many of the onotani I recorded in 1994-96 were performed by the friends of Sri Bunga Latar, a lady whose son at the time served as the government-appointed head of the village. She was no longer able to sing aloud and invited her female relatives from other parts of the village to sing at her house. Sri Bunga was famous for her knowledge of songs of Leb, Borut, and Latar. These lineages controlled the leading offices of the congregation at Banda Eli's principal mosque and the office of orangkaya. Sri Bunga herself came from the imam's family, and her female relatives claimed that her son's political position was based on their support.

Not all women of the orangkaya's house shared Sri Bunga's repertoire of songs. In 1996, I recorded several songs performed by Mustika Latar who, like Sri Bunga, had married into the Latar lineage. Unlike Sri Bunga, however, Mustika was also part of the orangkaya's house by birth. When her parents were married, this house was centered around a sibling set, which included her mother. Her father, who came from the other Banda-speaking village across the island, stayed in the house. Mustika's repertoire consists of songs owned by the Borut, Latar, and Takartutun-three lineages that belonged to the core group of the house before it achieved a leading political position in the village.

In addition, Mustika's songs recognize the Bandanese ancestry of the Fukar, a lineage identified as the servants of her father's ancestor. In the 1960s Mustika's father served as the imam, or Islamic leader of prayers, in Efruan, a subsidiary hamlet inhabited by commoners. The commoners of Banda Eli are generally Muslim converts from the surrounding Kei Islands society, but certain commoner groups claim that they, like the aristocratic lineages, originate from the Banda Islands. Mustika's father appears to have had close, affectionate ties to common people in Efruan. Therefore it is significant that one of Mustika's songs recognizes the claims of one subject group to ancestry in the Banda Islands. This is evidence of what Fabian (2007:92) calls "counter-memory," one that contradicts or relativizes the terms in which two groups define their relationship in public. 
Knowledge of onotani is embodied in women whose marital histories keep social structure in constant motion, as the constituting relations of each house keep changing over generations. This movement means that traditional performance reflects several different stances toward the interpretation of ancestral history among people who live at a certain moment. This is not simply a discourse that justifies political relations in the present. Women's development into performers takes place over long phases of their life, and their performances in weddings, funerals, and travel-related rituals mark their former and current membership in several houses. As the source of differentiated personhood, a woman's career as a singer parallels a man's career of inter-island travel.

The singers are conscious about their fame as performers. Many of those I worked with cultivated the memory of their most famous performances. The recurring story of several performers told how, years ago, a surprise performance in a wedding or a cultural festival had moved the audience to tears. The relatives of the singer who were present when I recorded the songs testified to the songs' effect on past audiences as well. To use the phrase of Elizabeth Tonkin (1992:43), such metadiscourse helps frame oral history as an "implicit autobiography." Ancestral and personal histories overlap in the embodied knowledge and authority over the songs, which singers themselves emphasize as a lifetime achievement.

Tonkin's ethnographic reference is a Liberian coastal community that, like Banda Eli, is aware of its past as a sovereign society of traders in spite of its present encompassment by another polity. Her comparison between two oral performances is of particular interest here. One is ostensibly an account of collective origin and migration but ends by telling about a war in which the narrator also participated and "suffered for his land" (Tonkin 1992:43). The other performance begins as a personal account but turns into a boasting chant of the narrrator's heroics, which expands the significance of the narrator's name and honor rather than the details and motives of his action (1992:48). In each narrative, personal experience comes through as a certain modality of participating in well-known events- "suffering" in the first genre and "honor" in the second. The result is a "story within a story," one that renders the narrator's self as "less than an individual personality than a social being" (Tonkin 1992:44). In the Banda Eli case, a singer projects her fame on both her actual life history and the ancestral past she sings about, foregrounding the latter as the deeper interpretation of the present.

\section{Form and Function in Onotani Songs}

The overt rhetorical function of onotani halia is to remind people about the connection (or, following Fabian's lead, contradiction) between the ancestral past and the present society. The narrative structure of onotani serves this rhetoric by collapsing together aspects of ancestral and present human experience. A more implicit connection between the two is produced by the characteristic style of onotani, which makes these songs iconic of "remembering" ancestors and absent, traveling relatives.

Dell Hymes's ethnopoetic method focuses on such implicit connections between form and function. In one example given by Hymes (1981:320), Chinookan narrators 
create verses of three lines that articulate the actions in the narrative with the flow of narration, as in "he was going along, he was go-ing, he got there." By such devices, the poetic organization of the discourse is interwoven with its rhetorical form and allows the storyteller to dramatize the story with different voices and attitudes (1981:321) that no longer appear as interrupting comments or "reports" (1981:83).

Bandanese onotani performers develop and carry on the theme of each passage of their songs by repeating and expanding the words of the first line. A short line that consists of a familiar name or phrase signals the beginning of a new sequence or action; in the next line, it is repeated and something is added to it, as if the narrative action progressed in parallel with the singer's efforts to recollect it. This stylistic device can be seen as a variant of anadiplosis, minding that, in contrast to anadiplosis in the usual sense, the repeated pattern is always in the beginning of the phrase:

The little girl Sambalain keeps crying

The little girl Sambalain keeps crying because it is dark

This use of anadiplosis is a way of producing measure (Hymes 1981:318): a formal pattern that marks diverse narrative elements as segments in a well-organized narrative performance. In Bandanese onotani, the repetition and elaboration of narrative motifs brings forth an increasing number of ideas about ancient and distant people, places, and events in order to reveal their connection to familiar persons, landscapes, and routines. The narrative concern of onotani with ancestral migrations and maritime travels points to sea travel as the chronotope in which people come face-to-face with ancestral realities and achieve self-awareness. It is in this sense that the Bandanese-a dispersed, seagoing people-identify onotani as the core of their cultural and historical knowledge.

Parallelism, verbal sequences that express the same thing in different ways or use different words to say the same thing, is a feature of the oral traditions of many Malayo-Polynesian languages (Fox 1977:63). Parallelism is not absent from Banda Eli verbal art, but in onotani performances, it often plays a second part to repetition, the precise reiteration of a particular line in the song. Gregory Forth (1988:154) points out that although the use of parallelism and repetition is sometimes rationalized as a way of ensuring the proper reception of the message, parallelism expands the message as if to make sure that it is understood. In lengthy onotani songs, anadiplosis seems to serve a similar purpose in underlining the hidden surplus of meaning in traditional expressions. Each repetition indicates that a familiar name or phrase contains more meaning than the audience can immediately recognize. In lengthy songs, repetition is also used to punctuate each segment of the narrative. In this way, repetition expands the meaning of recognizable fragments of traditional discourse even as it helps embed them in a larger plot.

Such formal devices have powerful entextualizing effects (Bauman and Briggs 1990:73). Repetition underlines the singer's claim to ancestral figures, events, and expressions; familiar expressions, images, and motifs are woven into a statement of a distinct, and somewhat inaccessible, domain of meaning and experience. Ultimately the rehearsal of a particular image throughout the song underlines the whole song 
as a distinct message. Banda Eli performers were reluctant to provide further explanations and comments on their own performances. When I asked other people to help me transcribe my onotani recordings, I found that they were not always happy with what they heard on tape. Instead of simply clarifying the original utterance, they kept adding parallelistic images to it, as if to improve the song's poetic qualities. By adding complexity to the song's text, these people affirmed their intimate knowledge of the genre it represented. Repetition and parallelism are therefore central for the entextualizing effects of onotani performance as well as for recontextualizing and valuing onotani performances as tradition (Briggs and Bauman 1992:148).

\section{The Self-Revealing Effects of Onotani Songs}

During my fieldwork in 2009, I had the opportunity to make new recordings with Mustika Latar, one of the Banda Eli singers whose performances I had previously taped in the spring of 1996. I will compare two versions of a song that Mustika performed on both of these occasions, thirteen years apart, in order to show which aspects of the song's narrative genre appear most stable and crystallized (Siikala 1990:80). The song I will discuss juxtaposes in a humorous way two narrative scenes: a heroic sea voyage and the effort of putting a child to bed.

This is a rough translation of the version performed by Mustika in 1996 (see figure 1 for a transcript of the original):

1. Greeting to the Old Ones and to God

2. Greeting to Mahmud, the seaman, and to Mbutak and Mboifulan, mothers of my people

3. Mahmud, the seaman, and Mbutak and Mboifulan, mothers of my people

4. I send you a message from far away, Lam and Alif, Bandanese

5. I send you a message from far away, Lam and Alif, Bandanese, in search of a golden ring [Ind.], a ring [Ban.]

6. If you go far away the haji must stay with me

7. If you go far away the haji must stay with me and care for me

8. The little girl Sambalain keeps crying

9. The little girl Sambalain keeps crying because it is dark

10. She wants to be lulled, she wants to be cradled

11. She pulls at the destar [turban] until I give it to her

12. She pulls at the destar and screams until I give it to her. They have hung the sarung [cloth cradle] ready [for her to sleep]

13. Thank God, I say to myself [lit. "inside my ear"]

The opening of the song marks it as onotani. The first two lines are a greeting to Mahmud, Mbutak, and Mboifulan, ancestral figures whom the singer claims as her forebears. On line 3 the song proceeds to describe Mahmud's sea voyage. The mention of two Arabic letters, lam and alef, indicates that this might be a pilgrimage to Mecca. But the song also points to the search for a "ring," a metonym of wealth, as another possible purpose of the trip. Lines 6-7 remind the traveling pilgrim about the small child who remains back in the village and cries after him. At this point, the 
scene of the narrative shifts to a room in which a haji (an old man wearing a pilgrim's turban) holds a crying baby in his lap. To the old man's relief, the baby calms down when she manages to grab the turban and pull it from his head.

I first recorded this song in March 1996. Mustika had invited me to visit her house on a rainy evening shortly before I left Banda Eli. The audience consisted of her children and their families: she clearly did not want the kind of larger audience of neighbors who usually came around when I was taping songs. Her dress and posture suggested that it was a prepared occasion. She had covered her head with a dark scarf, which she usually did not wear in public, and sat by the wall, avoiding the small talk with which her children greeted me. She performed a total of 12 short songs during a one-hour period. Except for our conversation during the recording, I did not have the opportunity to discuss the songs with her before we met again 13 years later.

I met Mustika again during my return visit to the village in the spring of 2009. I had not been able to give her advance notice when I came by her house, and therefore she had not had time to make any preparations for a song performance. When I asked her a few questions about the songs she had performed all those years ago, she asked if I would not rather hear more. On that occasion she performed a new version of one of the onotani I had recorded in 1996:

1. Greeting to the Old Ones and to God

2. Mahmud, the seaman, and to Mbutak and Mboifulan, the mothers

3. Mbutak and Mboifulan, mothers of my people, I send you a message from far away

4. I send you a message from far away, Lam and Alif, Bandanese

5. Lam and Alif, Bandanese, search for a golden ring [Ind.], a ring [Ban.], if you go far away from village and people

6. Haji is close if I put my child down

7. Sambalain keeps crying because it is dark

8. It is dark, she wants to be lulled, she wants to be cradled

9. She pulls at the destar until I give it to her

10. They have hung the sarung ready, thank God!

11. I say inside my ear

The corresponding lines of the two versions of this song in Bandanese are laid side by side in figure 1 . Comparing them reveals some of the conditions under which onotani retains its stability as a genre. The opening formula frames the song as a sacred, ancestral tradition. In later passages the singer has considerable liberty to develop playful motifs, such as the old man trying to deal with the tantrum of a child. In doing so, however, Mustika does not lapse into an ordinary speech register but keeps introducing such metaphors as nyoron tasik (plies the sea) (for sailing), or munjia raron sini (it is dark inside) (for nightfall).

The main difference between the two versions lies in how they manage the shift of scene from the heroic sea voyage to the humorous narrative about the old man handling the child. In the 1996 version, this shift is almost seamless and takes place when the song addresses the ring. The ring is a figure for the childlike yearning for valuable objects, but at the same time, it points to the might of the ancestors and the wealth produced by maritime trade. This parallel of meaning is sustained until the end of 
1996 version:

1. Sanggara tuano te Allahu tabea o tabea

2. Tabea Mahamud nyoron tasik a mbutak Mboifulan inani kai inamu aku

3. Mahamud nyoron tasik a mbutak $\underline{\text { Mboifulan ina ni ka inamu aku }}$

4. fa kusurat e fako rau te lam alef $m$ turi wandan

5. faku surat e fako raut te lam alef $m$ turi wandan cari cicin cari mamba

6. ji mbo rau nufa kai haji rinik ifa aku

7. jimborau nufa kai haji rinik ifa aku njaki aku

8. fa muruka Sambalain jaga m raut

9. fa muruka Sambalain jagam raut fa munjia raron sini

10. re ndoro fa keno-keno te ndolo fa salosalo

11. ndoro destar e in tenein fa ku ndili

12. neloro destar e in kanggit fa ku ndili saron nafu ke reliliki

13. ire Alhamdullillah i rarono taninga
2009 version:

1. sanggara tuano te allahu tabea o tabea

2. Mahamud njoron tasik a mbutak Mboifulan ina

3. mbutak mboifulan ina ni kai namu aku faku surat e faku rau

4. faku surat te fako rau te lam alif ma turi wandan

5. lam alif ma turi wandan cari cicin cari mamba njifo rau nufa kai

6. haji rinik ifa aku njake aku fa muruk

7. sambalain dagam raun fa munjia raron sini

8. fa munjia raron sine re ndolo fa kenokeno te ndolo fa salo-salo

9. ndoo destar e in kami fa ku ndili

10. saron nafu ke reliliki e re alhamdulillah

11. rarono taninga

Figure 1.

the song: the child keeps trying to grasp objects that substitute for the mother's nurturing figure and ends up pulling off the venerable haji's turban.

In the 2009 version of the song, Mustika uses similar metaphors and formulaic expressions as in the recording from 1996, but in this version, they appear as memory-aiding devices. Cari cicin cari mamba (Looks for ring, looks for ring) in line 5 is a parallelism in which the words cincin, lifted from Indonesian, and the Bandanese word samba appear in slightly altered form. This line marks the shift between the two scenes. In the 2009 version, the shift does not take place through poetic elaboration of the previous figure but uses a more literal expression, spoken from the mother's perspective (line 6: haji rinik ifa aku njake aku fa muruk) (Haji is close if I put down my child for a while). As a result of this, line 6 stands out as an external comment about the narrative, or what Hymes called "report" (1981), instead of a smooth transition to the childrearing scene.

What I have called anadiplosis in fact follows a rhythmic pattern: shorter phrases alternate with longer ones; the next theme emerges dreamlike from the previous one. Virtuosos are able to keep this flow going in long, narrative songs, even if they also 
use repetition to mark the beginning of a new passage and to underline expressions that convey the narrative agenda of the song as a whole.

The recording I made with Mustika in 1996 approximates what Hymes called full performance. Instead of reproducing a previously composed work, the singer composes the song as an artistic whole while she is singing, as Albert Lord (1960:17) suggested in studying Serbian singers. Anadiplosis and parallelism are central elements of the technique of composition used by onotani singers. Performance in front of different audiences is necessary for mastering such techniques, and the stories of Banda Eli singers suggest that they have learned their skills gradually during their performing lives (Lord 1960:21).

\section{Cultural Reproduction among the Urban Bandanese}

The Bandanese who grow up in town are at a double disadvantage in trying to master this technique of composition. They learn Indonesian instead of Bandanese as their first language. Although many people make a conscious effort to learn Bandanese later in life, they are only able to use it for easy everyday conversation. Much of the specialized vocabulary used in onotani songs is obscure to them. In addition, few urban weddings and funerals are accompanied by traditional performances. Aspiring singers no longer have access to the arenas of public performance in which villagebased singers learned their skills. The decline of linguistic competence and performing practice contribute to language shift, a process in which the use of local languages such as Bandanese is restricted to everyday conversation. Ultimately, as Webb Keane (1997:52) suggests for the local languages of Sumba, people may find that there is no point in using the local language since it no longer represents a distinct semiotic resource, capable of carrying meanings that differ from the national language.

I could not avoid this pessimistic view when I observed how aspiring singers wrote down lyrics from the tape-recorded songs of their grandmothers. Instead of beginning as peripheral participants of a living verbal art, as their predecessors had done, they seemed to learn the songs by rote. But if we look at onotani as a shifting perspective of what traditional discourse means, it is not justified to see writing merely as an inferior method of handing down oral tradition. It is possible that the urban Bandanese were oriented by literary models of knowledge, no less authentic than oral performance from their own point of view.

The coastal peoples of Maluku have been part of a literary culture at least since the sixteenth century. Indigenous literature in Malay (Manusama 1977) and long-distance communication by letters (Schrieke 1955:34; Collins 1996:15) was clearly present in Maluku during the early colonial era. As I will show in the last section of this article, certain people of Banda Eli carried on this tradition of Malay literacy, which clearly included the Bandanese as well.

The point I want to make here is that literacy is not a neutral, transparent medium of discourse. Just like singing and storytelling, written discourse arises from a process of linguistic interaction (Finnegan 1992:15). Composing an oral narrative text is not fundamentally different from composition in print culture (Sweeney 1987:12). And 
whereas a lot of anthropological theorizing of literacy has taken it as a technology of recording discourse (Goody 1977; Ong 1977), many indigenous models of writing are informed by different modes of oral performance (Fabian 1993:92).

I had no written material to help my study of the Bandanese language, and this made me sensitive to the way Bandanese people anticipated how their writings would sound if they were read aloud. When they wrote a letter in the national language of Indonesian, they took into account the letter's potential semi-public audience and used polite, stilted phrases of greeting and address. In their quick, informal, personal messages, on the other hand, they used Bandanese, which allowed them to address the recipient much more directly-dispensing with formal phrases of address, as they would also do in addressing a small gathering of people in their own language. Starting in the late 1990s, this domain of local language usage has expanded to short messages sent from mobile phones. Another interesting genre of writing is the list. When people scribble personal or place names, ritual actions, or the lyrics of a traditional song in a school notebook or on a torn piece of paper, they usually signal textual completeness by presenting this writing as an itemized list of information.

Yet another perspective on writing opens up when we consider the fact that most Bandanese achieve a certain degree of literacy in both Latin and Arabic letters by the approximate age of 13. The function of their knowledge of the two alphabets is obviously quite different. The recitation of the Koran happens without the full comprehension of Arabic, the language in which the Koran is written. James Baker (1993:98) argues, however, that people are still expending real time and personal effort in actualizing the inscribed words in a temporal sequence. In a way that is not completely different from an itemized list, Quranic recitation puts people in the presence of a traditional, textual discourse that calls for interpretive agency.

According to Baker, what is crucial for this agency is not the ability to comprehend but to "apprehend" the text that is being read. The sense of it as ordered discourse gives it a persuasive power that extends to various contextualizing and exegetical narratives. The Bandanese often speak about traditional songs as the "proof" (Ind. bukti) of such explanatory discourse. In the larger context of reading practices, the apparent rote learning of these songs turns out to be a meaningful social practice. The public rehearsal and performance of the songs stimulates a broader conversation on cultural topics. Their archaic words and phrases present the contemporary audience with a riddle to solve.

In 2006, on a brief visit to Indonesia, I had the opportunity to test the ability of urban Bandanese to understand onotani songs recorded with village performers in 1996. I invited Bandanese who had lived in Jakarta, the Indonesian capital, for most of their adult lives to help me transcribe formerly unprocessed recordings and to translate them into Indonesian. On first listening to a taped song, they were as puzzled as I was about its exact meaning. After a while, however, someone would work out a possible interpretation of its main themes and motifs, helping others to guess the normal form of a bent or unclear word. The linguistic register of the songs differs from everyday Bandanese to such an extent that my collaborators had to rely on their cultural knowledge to interpret them. The insight came when someone recognized 
an obscure word for an ancestral name, or realized what cultural or religious issuesfor instance, a soul's journey to heaven - the song dealt with. ${ }^{3}$

I suggest here that the interpretation of the texts has something in common with the performance of the songs from which they derive. Our transcribing exercise turned the song's scenes and images into familiar cultural insights that recalled a discussion with a close relative. As I have suggested in my analysis of Mustika's performance, the ancestral past that suddenly collapses into the here and now is the defining chronotope (Bakhtin 1981:81) of onotani songs. Charles Briggs (1996:449) calls attention to the diverse structures of feeling produced by such contrasts and alignments between different discursive worlds. Nostalgic traditionalism is one mode of juxtaposing the present and the past, but it is far from the only one. In the remainder of this section, I describe several contemporary situations in which people from Banda Eli construct various degrees and modes of distance between their ancestral culture and their present realities.

My first example is a case of traditionalization, a rhetoric in which culture is distantly embodied in the past. In 1990, a group of Bandanese residing in Ambon met in a café and founded an association called "Society of Growing Bandanese." This group included teachers, civil servants, and university lecturers, several of whom had higher education. One of the performances they staged took place in 1992 during the International Diving Contest in the Banda Islands, which the Bandanese performers claimed as their ancestral homeland. This performance took place at the invitation of Des Alwi, the nationally known hotel owner and the adoptive son of Mohammed Hatta, the first vice president of Indonesia, who was interned in Banda during the 1940s.

To visiting international divers, Bandanese dances and the onotani tambola songs must have appeared as a fairly standard folkloric performance. To the Bandanese participants whom I interviewed afterward, the most memorable part of the event was a pageant, scripted in Indonesian, in which the ancestors of the Bandanese declared their resistance to Jan Pieterszoon Coen, the Dutch governor-general, during the colonial conquest of Banda in 1621. Their performance gave less emphasis to establishing cultural continuity than to claiming a distinct role for the Bandanese society within the discourse about colonial and national history. The generic interest in local culture is therefore motivated by a specific dialogue between two diasporic groups-the Bandanese and the Arabs, represented by Des Alwi-each of which claims a prominent role in the historical trade networks of Maluku.

During my 2009 fieldwork, a new generation of students founded another cultural society, the "Association of Bandanese Students." The older association was suffering from factional divisions in the community after some of its officials were appointed to important government positions. One purpose of founding the new association was to heal such divisions and to demonstrate the shared commitment toward Bandanese culture among the younger generation. Founding the association was a lengthy process, part of which I was able to observe during my residence in Ambon. It took a couple of months before the student organizers had convinced the leaders of each segment of the urban Bandanese community to support their initiative. Meanwhile a group of dancers and singers were preparing a performance that 
included folk dances and onotani tambola songs. In a gesture toward the unifying effect of marriage ties between patrilineal groups, the songs chosen for this performance celebrated the beauty of Bandanese women.

These two examples suggest that urban folkloric performances are not just generic signs of an ethnic identity. They are carefully tuned to convey specific messages about the ancestral culture and to stress people's historically continuing relationships to significant places and to each other. This is evidence of a persistent metadiscourse about tradition that, in public folkloric performances, tends toward a nostalgic rhetoric in which culture is embodied in a distinct kind of ancestral past.

There is a different sense in which people continue to revive and enact old ethnic alliances by the means of tradition. As I have already mentioned, the Bandanese cultural knowledge about distant others is a means for maintaining and reviving alliances with groups that live far outside the Kei Islands. In 1976 a number of men from Banda Eli went to see the leader of a powerful landowning clan in Ambon, the provincial capital, in order to ask him for construction land. They performed for him a passage from an onotani about Boiratan, a Bandanese ancestress whom several societies of Central Maluku recognize as a cultural heroine. In this case, the landowning clan descended from Boiratan's son. Through this performance, and the metadiscourse surrounding it, the Bandanese claimed that they were distant kinsmen to the Ambonese group. This claim was accepted by the landowners, who granted the Bandanese the right to mine sand from the sea bottom and build a landfill for their houses in the southern part of the city.

This successful invocation of tradition and the resulting ethnic alliance between Ambonese Christians and the Bandanese Muslims is a cause célèbre among Banda Eli people. Similar alliances exist between Banda Eli and other villages in the Kei Islands. These alliances are dramatized during national and religious holidays when people from one village make ceremonial visits to another village by boat. Before the visitors can land, a man standing in the bow of their war canoe has to perform a song that draws the appropriate response from another singer on the shore.

Such ritual expressions of amity between local groups of different faith were appreciated as a peacemaking device during the ethnic warfare that broke out in $\mathrm{Ma}$ luku after the fall of the Suharto government in 1998. While the two parties perform their songs in different linguistic registers and styles, the persons specialized in performing them are usually familiar with both the challenge and the response. Studying lost family heritage is therefore possible by tracing such specialists among the allied group and learning one's own songs from them.

The lesson to be learned from these examples is that tradition does not consist of precisely defined texts and performing styles. The nature of performance, and the genres used in them, depends on metadiscursive views about the power of certain texts and fragments of knowledge to affect a certain kind of audience. As Keane (1997:41) puts it, this power does not reside so much in the semantic content of archaic songs and ritual speech but in the intersection of their formal properties and the speakers' capacity to mobilize them. As I will argue in the next section, this does not exclude writing as an effective means of cultural reproduction, particularly when writings are framed as textual objects with a certain life of their own. 


\section{Writing Down the Past}

The old, village-based oral performances rely on techniques of oral composition, whereas urban people increasingly reproduce tradition as texts. We should be cautious about interpreting this as a complete shift from oral to written tradition. Onotani performers often point to their song as a "message," or literally "letter," addressed to the ancestors. As I have illustrated with reference to Mustika's song, these songs typically collapse distant, ancestral reality with the time in which the singing itself takes place. Ancestors-the source of the songs' textual authority-appear to be removed from the present in space, rather than time. Oral performance suggests that the same form of authority is still present in the elders; it helps the participants imagine mundane interactions with them as the context in which tradition is handed down. But when the meaning of traditional discourse is circulated across times, places, and generations, the form of its expression tends to become fixed. As Greg Urban (1996:25) puts it, meanings are made sensible not by "enactment, but by holding constant the physical form of their expression." Handing down tradition is replaced by writing it down.

The interesting question is how writers try to control the circulation and meaning of their texts. William Hanks (2010:103) points out that different genres of writing are grounded in time and place in distinct ways. Written records can either point to specific acts and moments in time as the source of their authority or leave their readers to manage their intertextual links and gaps (Hanks 2010:110; Briggs 1996:449). Whichever alternative they choose, people who turn oral traditions into documents cannot rely on a particular genre of writing because models of authoritative discourse change over time. For this reason, they tend to mix different writing genres and address multiple audiences with their text. The resulting texts are confusing and full of "blank spots" that the reader must fill in with meaning (Hanks 1989:105).

Writing down tradition thus results in what Hanks (1987:677) describes as "boundary genres." These genres are not produced within a stable system of rhetorical functions and verbal forms. Instead, they use the rhythm, sequence, and duration of familiar modes of practice as an index of similarity between past and present realities. The textual traditions I recorded in Banda Eli concretize the time and space of the ancestors by quoting their precise words and by describing their familiar activities (such as praying at noontime or relieving oneself at the seashore early in the morning). By reporting such details, the narrative grounds itself in a specific kind of past.

The most intriguing boundary genre I found in Banda Eli was the chronicle kept by an old man with whom I worked intensely for several months in 1994. His name was Kende Serwowan, and he held the ritual title of kapitan in the village of Banda Eli. I came in contact with him after I had explained my research interests to an assembly of old men. When I told them I was interested in local history, they seemed a little nervous, as if they expected they would need to address difficult, politically charged questions. They were visibly relieved when they realized I would only have to go to Kende, the famous scribe, who already had their history in writing.

Kende's manuscripts consisted of diverse oral accounts that he had recorded from several sources over his long life. He kept writing down the traditions of his village 
in school notebooks, using the Malay language and Arabic script, until his death in 1997, soon after my fieldwork ended. Kende had apparently begun writing already in the 1930s when he preceded Mustika's father as the imam of Efruan. At this time he collected songs and stories that justified the independent claim of Efruan's inhabitants to their part of village land. In other writings, Kende described his ancestors' marriage relations to the family of the Sultan of Tidore, one of the small trading states of North Maluku. Yet other texts dealt with the political history of Banda Eli and its relationship to the Kei Islands chiefships. In addition to these topics, Kende had written lengthy, detailed accounts about the Islamic conversion of the Bandanese ancestors, their war with the Dutch conquerors, and the political symbols of Golkar, the dominant national party of the 1990s.

Kende's chronicle has a puzzling style that results from his deliberate attempt to address multiple audiences at the same time. The titles of his narratives point to foreign genre categories such as "genealogy" (silsilah) and "history" (sejarah). At one point he refers to a Sufi tariqa to which his ancestors were affiliated as his source on the history of Islam. While Kende's texts were obviously related to Islamic literary networks that span across Asia (Ricci 2011), his intention was not to produce a literary work that was completely in line with their genres. Instead, he finalized his texts as if they were official documents. An anecdotal story from decades ago, for instance, mentions precise hours of the clock as if it were a modern court record. Aside from this documentary style, the narratives contain word-for-word reports of incantations characteristic of ritual speech. Kende's manuscript was a package of different types of powerful speech, designed to evoke an evaluative response in all the kinds of audiences that he had faced during his writing career.

The early months of my fieldwork turned into a kind of office work as Kende took me systematically through his manuscripts. I spent long hours in his house, typing stories from his dictation and reproducing the original pages by photography. Carbon copies of what I typed stayed with Kende, adding to his hand-written volumes. Finally he declared to me that the work was "complete" and told me I should go and ask the other elders if they agreed with his account of the events. But there was a catch: I was not allowed to show my copies of the chronicle to anyone in the village.

Later Kende qualified this requirement. I would be free to discuss his chronicle in scientific conferences and publications, and pretty much with anybody who did not live in his village. Perhaps he anticipated the ethical dilemma I would face when I later met his relatives, who lived in a second home in the city. He certainly did not have any problem showing my copies of his text to visiting relatives who lived elsewhere. One was the head of freight services in the Bali airport, another was a soldier living in Borneo, and a third worked for a foreign company in Central Maluku. The only real secret was the compilation, the entire chronicle.

In 2009 I learned what had happened to it when he died. The writings were divided and given to family living outside the village. I met one of his relatives on a visit to Waisarisa, a sleepy industrial settlement on the coast of Seram. This man, Kende's sister's grandson, looked me deep in the eyes and asked what Kende had given me. I gave a quick outline of the topics of his writings. "Did he give you this one?" he rhetorically asked, showing me a pile of foolscap manuscripts I had typed fifteen years earlier. 
Kende's orders of disclosure reflect his thinking about the difference between genre and text. On one level, we should think about his chronicle as a finished whole, a "complete" work as he put it. On another level we should take it as a new genre, a way of presenting traditional discourse that responded to my initial quest for "local history." The former interpretation applies to Kende's role as the village scribe. His house had a little window from which people could see his head at sunset as he was reading aloud what he had written during the day. When he discussed his writings with me, he cultivated similar parallelistic expressions that abounded in his texts. He used such phrases as tewas dan korban (fallen and victims) in reference to the casualties of a communal conflict, and taat dan patut (to obey and respect), to describe a submissive attitude toward cultural authority. This shows that Kende was not merely representing and translating traditional genres: his metadiscourse of tradition made constant use of their linguistic forms. To people who were familiar with these genres, Kende's metadiscourse pointed to his personal knowledge as an archive of traditional texts that had accumulated in the specific conditions and political projects of his life.

By saying that his chronicle was complete, Kende was thus referring to his ability to close an intertextual gap between his own speech and a variety of traditional texts. At the same time, Kende recognized that his interpretation of Bandanese history and culture was bound to be one stance among many, among outsiders. Before I appeared in front of him with my questions, he had already been consulted and confronted by numerous traditional leaders, religious and state authorities, and educated urban relatives. As a particular kind of cultural authority, a "chief who speaks outside the house," Kende identified himself with such outsiders. In order to position himself at the same level with these outsiders, he responded to foreign expectations of genre. This method of managing the intertextual gap between authoritative texts from different sources is fully recognized in the Banda Eli linguistic ideology, even if it breaks the forms and patterns of language identified with ancestral messages.

\section{Conclusion}

Throughout this article, I have stressed the efforts of the Bandanese to reproduce their tradition in new settings. Such genres as onotani are necessarily "multimodal" (Hanks 2010:112). The actors involved in reproducing them employ a diversity of semiotic resources, and their performative acts are variously embedded in larger cultural and historical contexts of activity (Goodwin and Goodwin 2004:239). The question about the reproduction of tradition is therefore not how people can maintain specific aesthetic and artistic forms. It is more interesting to ask what makes it possible to organize oral and written discourse into a form that carries the revealing, exemplary powers of language.

The examples discussed in this article suggest that such reorganization of tradition often happens through the interplay of oral performance and writing. The technology of writing as such does not have to change the structure of oral performances in a fundamental way: it may simply be used as a remedy for the erosion of the "ecology" of oral tradition (George 1990:18). A more fundamental issue is: Does writing down tradition reproduce it as culture? 
The scholars who have explored tradition as a metadiscourse affirm that it does. Kende's collection of traditional discourses may at first sight seem to be the opposite of Mustika's full-fledged poetic performance. But both are oriented by cultural categories that define their position in a larger world of discourse. This world is not limited to the Bandanese community. I share the hesitation shown by the Bandanese themselves to talk about a distinct Bandanese culture. But they are certainly part of a larger historical world of Maluku in which people recognize the significance of origin narratives, ancestral names, and local language poetry. For many people this world extends to global Islamic networks, in which people like Kende also claim to belong.

When tradition is present as a metadiscourse, it ensures the continuing circulation of discourse. When Greg Urban proposed this notion, he was interested in the empirical conditions of accessing the meaning of experience (Urban 1996:5). Cultural meanings live on when they are enacted as discourse, and the discourse that can be enacted in a prescribed form has the best chance of circulating. This argument implies that traditional discourse propels itself toward a certain universality: it is not a statement about identity but humanity.

We must note, however, that Mustika and Kende clearly did not want their repertoires to circulate as public discourse. This suggests that the production of traditional discourse is not only driven by the impulse to make it public, but equally by the impulse to possess and preserve (Fabian 2007:94). The reluctance of Banda Eli singers to pass on their songs reminds one of Peter Metcalf's (2002) account of the old lady in Borneo who recognized his information about shamanism as correct but refused to be the source of that information. Storytellers claim mastery in the ways their stories are told (Bauman 1975:294), even if they make no claim to the truth of their stories (Bauman 1993), and sometimes call them lies (Fabian 2007:100).

Such metadiscourse frustrates any attempt to establish a canon of cultural texts. It instructs future generations to move culture into new places and to make public claims to it in front of new audiences. It leaves future performers with a hidden message to claim for their own. I have argued that the impulse to discover it is still there although the language of tradition is being lost. We have also seen that the old performers obscure and disperse the tradition they are passing on. They withhold tradition as collective memory from their successors but entice them to remember the personal biography of their forebears. The desire for sharing the past can only be satisfied by following their travels, performances, and relationships.

\section{Notes}

1. My fieldwork in the Kei Islands took place over 15 months in 1994-96, with funding from the Academy of Finland and the Väinö Tanner Foundation and the sponsorship of the University of Gajah Mada, Yogyakarta. In 2009 I did fieldwork in Ambon and the Kei Islands as a senior scientist of the Academy of Finland, sponsored by the Indonesian Institute of Sciences (LIPI) at Jakarta and Ambon. I would like to express thanks to these agencies and the Banda Eli community for their generous support to my research. Versions of this paper were presented at the 8th International Summer School of the Folklore Fellows at Lammi in 2010, and at the Conference of the Finnish Anthropological Society at Helsinki in 2011. In addition to the organizers and participants of these meetings, I would like to thank the two anonymous readers of this article for their encouraging and constructive comments. 
2. Important musical elements of onotani are beyond the scope of this essay. Onotani and other types of songs performed in Banda Eli and the surrounding villages employ a number of modal scales that, together with rhythmic patterns, mark their distinction as genres. It appears that different performers have developed their own singing styles, and there is no effort to maintain a uniform style of delivery beyond the qualities mentioned here.

3. Many onotani deal with expressly religious themes. One of the onotani discussed in Jakarta tells how every question of the ancestor, after his death, is answered by the Angel of Death "as swiftly as the wind, as quickly as the sea." A similar awe at Prophet Muhammed's ability to anticipate and give an immediate answer to the questions of Islamic converts is a recurring motif in the Book of One Thousand Questions, an Islamic literary corpus which circulated widely in India and Southeast Asia in the early twentieth century (Ricci 2011:193). It is likely that such written traditions have for a long time been connected to oral traditions such as the onotani.

\section{References Cited}

Baker, James. 1993. The Presence of the Name: Reading Scripture in an Indonesian Village. In The Ethnography of Reading, ed. Jonathan Boyarin, pp. 98-138. Berkeley: University of California Press.

Bakhtin, Mikhail M. 1981. The Dialogic Imagination. Austin: University of Texas Press. 1986. Speech Genres and Other Late Essays. Austin: University of Texas Press.

Bauman, Richard 1975. Verbal Art as Performance. American Anthropologist 77(2):290-311.

1993. Disclaimers of Performance. In Responsibility and Evidence in Oral Discourse, ed. Jane H.

Hill and Judith T. Irvine, pp. 182-96. Studies in the Social and Cultural Foundations of Language Series, 15. Cambridge: Cambridge University Press.

- 2004. A World of Other's Words: Cross-Cultural Perspectives on Intertextuality. London: Blackwell.

Bauman, Richard, and Charles S. Briggs. 1990. Poetics and Performance as Critical Perspectives on Language and Social Life. Annual Review of Anthropology 19:59-88.

Blommaert, Jan. 2006. Ethnopoetics as Functional Reconstruction: Dell Hymes' Narrative View of the World. Functions of Language 13(2):255-75.

Briggs, Charles. 1996. The Politics of Discursive Authority in Research on the "Invention of Tradition." Cultural Anthropology 11(4):435-69.

Briggs, Charles, and Richard Bauman. 1992. Genre, Intertextuality and Social Power. Journal of Linguistic Anthropology 2(2):131-72.

Collins, James T. 1996. Malay, World Language of the Ages. Kuala Lumpur: Dewan Bahasa dan Pustaka.

Collins, James, and Timo Kaartinen. 1998. Preliminary Notes on Bandanese: Language Development and Change in Kei. Bijdragen tot de Taal-, Land-en Volkenkunde 154(4):521-70.

Errington, Joseph. 1998. Shifting Languages. Interaction and Identity in Javanese Indonesia. Cambridge: Cambridge University Press.

Fabian, Johannes. 1993. Keep Listening: Ethnography and Reading. In The Ethnography of Reading, ed. Jonathan Boyarin, pp. 80-97. Berkeley: University of California Press.

- 2007. Memory against Culture. Arguments and Reminders. Durham, NC: Duke University Press. Finnegan, Ruth. 1992. Oral Traditions and the Verbal Arts. A Guide to Research Practices. London: Routledge. Forth, Gregory. 1988. Fashioned Speech, Full Communication. In To Speak in Pairs, ed. James Fox, pp. 129-60. Cambridge: Cambridge University Press.

Fox, James. 1977. Roman Jakobson and the Comparative Study of Parallelism. In Roman Jakobson: Echoes of His Scholarship, ed. Daniel Armstrong and C. H. van Schooneveld, pp. 59-90. Lisse: Peter de Ridder Publishers.

1988. Introduction to To Speak in Pairs, ed. James Fox, pp. 1-28. Cambridge: Cambridge University Press.

George, Kenneth M. 1990. Felling a Song with a New Ax: Writing and the Reshaping of Ritual Song Performance in Upland Sulawesi. Journal of American Folklore 103(407):3-23.

Goodwin, Charles, and Marjorie Harness Goodwin. 2004. Participation. In A Companion to Linguistic Anthropology, ed. Alessandro Duranti, pp. 222-44. Oxford: Blackwell. 
Goody, Jack. 1977. The Interface between the Written and the Oral. Cambridge: Cambridge University Press.

Hanks, William. 1987. Discourse Genres in a Theory of Practice. American Ethnologist 14(4):668-92. 1989. Text and Textuality. Annual Review of Anthropology 18(1):95-127.

1996. Language and Communicative Practices. Boulder, CO: Westview Press.

2010. Converting Words. Maya in the Age of the Cross. Berkeley: University of California Press.

Hymes, Dell. 1981. "In vain I tried to tell you": Essays in Native American Ethnopoetics. Philadelphia: University of Pennsylvania Press.

Kaartinen, Timo. 2010. Songs of Travel and Stories of Place. Poetics of Absence in an Eastern Indonesian Society. No. 299. FF Communications. Helsinki: Suomalainen Tiedeakatemia.

Keane, Webb. 1997. Knowing One's Place: National Language and the Idea of the Local in Eastern Indonesia. Cultural Anthropology 12(1):37-63.

Kuipers, Joel. 1990. Power in Performance: The Creation of Textual Authority in Weyewa Ritual Speech. Philadelphia: University of Pennsylvania Press.

. 1998. Language, Identity and Marginality in Indonesia: The Changing Nature of Ritual Speech on the Island of Sumba. Cambridge: Cambridge University Press.

Lord, Albert. 1960. The Singer of Tales. Harvard Studies in Comparative Literature Series, 24. Cambridge, MA: Harvard University Press.

Manusama, Z. J. 1977. Hikayat Tanah Hitu: Historie en Sociale Structuur in Ambon. PhD diss., University of Leiden.

Metcalf, Peter. 2002. They Lie, We Lie. Getting on with Anthropology. London: Routledge.

Ong, Walter. 1977. Interfaces of the Word. Ithaca, NY: Cornell University Press.

Pemberton, John. 1994. On the Subject of "Java." Ithaca, NY: Cornell University Press.

Ricci, Ronit. 2011. Islam Translated. Literature, Conversion, and the Arabic Cosmopolis in South and Southeast Asia. Chicago: University of Chicago Press.

Schrieke, Bertram J. O. 1955. Indonesian Sociological Studies. Vol. I. The Hague: van Hoeve.

Siikala, Anna-Leena. 1990. Interpreting Oral Narrative. No. 245. FF Communications. Helsinki: Suomalainen Tiedeakatemia.

Siikala, Anna-Leena, and Jukka Siikala. 2005. Return to Culture: Oral Tradition and Society in the Southern Cook Islands. No. 287. FF Communications. Helsinki: Suomalainen Tiedeakatemia.

Silverstein, Michael, and Greg Urban. 1996. The Natural History of Discourse. In Natural Histories of Discourse, ed. Michael Silverstein and Greg Urban, pp. 1-17. Chicago: University of Chicago Press.

Sweeney, Amin. 1987. A Full Hearing. Orality and Literacy in the Malay World. Berkeley: University of California Press.

Tonkin, Elizabeth. 1992. Narrating Our Pasts. Cambridge Studies in Oral and Literate Culture, 22. Cambridge: Cambridge University Press.

Traube, Elizabeth G. 1986. Cosmology and Social Life. Chicago: University of Chicago Press.

Urban, Greg. 1996. The Metaphysical Community. The Interplay of the Senses and the Intellect. Austin: University of Texas Press. 